\title{
The Analysis of Policy Objectives and Economic Effects of House Property Tax
}

\author{
Qiang $X u^{1}$, Hongzhu Yue ${ }^{1}$ \\ ${ }^{1}$ School of Economics, Sichuan University, Chengdu, Sichuan Province, China
}

Keywords: House Property Tax; Market Bubbles; Policy Objectives; Economic Effects.

\begin{abstract}
The real estate bubble has seriously threatened the healthy and stable operation of economy and society in China. It is urgently required for the government to regulate the real estate market by the house property tax. This paper firstly analyzed the reason of high housing price and discussed the policy objectives of the house property tax in a normative analysis way. Then it analyzed the economic effects after carrying out the house property tax comprehensively. The corresponding policy suggestions are given in the end of the paper.
\end{abstract}

\section{Introduction}

The bubble formed from the quickly increased housing price over the years has been a hidden danger to the society stability and economy health of China. In the past, the government has taken a number of measures to regulate the overheating of the property market, but had little success. On the contrary, it caused a strange phenomenon of "The more it regulates, the higher the housing price is". The Central Economic Working Conference at the end of 2016 pointed out clearly that the regulation of the real estate market should insist on the position that the house is for living not speculating. It released a signal of deepening the regulation of the real estate market. The house property tax, as an important measure of the real estate market macro-control, has been the spotlight of all the society.

The academic community is divided over the possible economic benefits of the house property tax. Most scholars hold a positive attitude. Like Gang Fan(2007), Kang Jia(2013), etc. They affirm the role of house property tax in restraining the real estate bubble and regulating the income distribution and so on. However, some scholars think in a contrary way. For example, Baisan Xie(2015) thinks the tax is regarded as a direct tax, and taxpayers' tax compliance is low. Yang Yan(2017) thinks due to the demand rigidity in the rental market, the house property tax will be passed on to the renters, which will fail to achieve the desired effect.

\section{Reasons of High Housing Price}

The Analysis of Component Factors of Housing Price. To explain the reasons of high housing price, we should start from analyzing the factors composing the housing price and study each factor so that we can find the focus of the regulation policy. The housing price can be divided into four parts: taxes and fees "T" (including land-transferring fees and other kinds of taxes and fees); building cost "C"; the reasonable profits of real estate enterprises "R" and the market bubble price " $\varepsilon$ " (including the developer's excess profits and second-hand housing market profits). Therefore, the price of commercial residential buildings can be expressed as:

\section{$P=T+C+R+\varepsilon$}

The housing prices differ from districts, but the building cost " $\mathrm{C}$ " are with little difference. Thus, in the housing price composition, the factors The factors that contributed to the rapid rise in housing prices are taxes and fees "T" levies by the government and the real estate bubble price " $\varepsilon$ ". The taxes levied by the government include such taxes as land-transferring fees, land use tax, cultivated land occupation tax, land value added tax, house property tax, business tax and income tax, etc. Although taxes levied by the government make up a different proportion of the property price in different geographies, it is a fact that there is a high proportion in general. Take land-transferring fees as an example. According to the official statistics of the Land and Resources Ministry, the price of land auction for residential property has increased by about five times from 1,184 yuan per square meter in 
early 2005 to 5,918 yuan per square meter by the end of 2016.1 On the other hand, the market bubble price " $\varepsilon$ " is the main reason for overpriced housing. At present, because of the imperfection of China's financial market and the lack of investment channels, a large number of speculative arbitrage funds swarm into the real estate market, which makes real estate detract from the essential attribute of residence and become a kind of investment. The market bubble is characterized by high housing prices and high inventories. According to statistics released by the Chinese Household Financial Research and Study Center of Southwestern University of Finance and Economics, The housing vacancy rate in 2013 was $22.4 \% .2$ There is a huge market risk in the real estate market bubble.

Analysis of Supply and Demand Elasticity. Housing once became a kind of market trading goods, the price is decided by the balance of supply and demand. The internal cause of the excessively rapid growth in housing price is insufficient demand elasticity. It is reflected in two levels: commercial housing market and land auction market.

In the commercial housing market of our country, the composition factors of rigid demand are numerous. It can be divided generally into two kinds: The demand for the "residential" attribute and the demand for the "investment" attribute of commodity houses. China is at an accelerating stage of urbanization. There is a large number of rural people moving to cities each year and they need to buy houses. Under the urban and rural dual structure household registration system, the purchase of houses is not only for solving the problem of living, it even stands for the urban household register, which means they can get more high-quality public products such as transportation, education and health care. What's more, living and working in peace and contentment is a part of the traditional Chinese culture, so the demand for commercial housing is expanding. On the other hand, the financial market in our country is still not perfect, investment channel is comparatively lacking, so a lot of money considers commercial housing as the investment subject to preserve or increase its value, which further exacerbates the rigid demand of the commodity house.

The demand rigidity of the commercial housing market is bound to be transferred to the land auction market. The rigid demand of the residents for the commercial housing motivates the rigid demand of the developers for the land resource. However, the land resource is limited by the local government which leads to the lack of supply elasticity. By controlling the supply of land, the government is able to influence the price of land sales and eventually transfer it to the commercial housing market.

So essentially, the lack of supply in the land auction market and the demand rigidity in the commercial housing market leads to the rapid growth of house prices.

\section{The Policy Objectives of House Property Tax}

According to the theory of institutional change, the government leading institutional change and gradual institution change are the types of China. (Tianxiang Chen, 2001)3. The implementation of the real estate tax system is the individual institutional change of China's tax institutional change(local system). It still has the attribute of the government leading and gradual change. From the view of system demand, excessive growth of the housing price has a negative effect to society and people's livelihood. Based on the self interest, the ideal institutional supply appeal for most residents is restraining or reducing the price of real estate without reducing the supply of government public products. However, under the institutional change mode in our country, when the government decide the institutional supply of real estate tax system, considering residents' demand for system, they should also consider factors such as fiscal revenues and social justice. the government's objectives are multiple.

In regard to the policy objectives of house property tax reform, synthesizing academic discussions, it can be summed up in three points: achieving fiscal revenue, adjusting income distribution, and regulating the real estate market. 


\section{Economic Effects of House Property Tax}

The institutional change inducements are from the potential profit opportunities exist in the institutional imbalance. But in the process of institutional change carried out by the organizations, the uncertain factors make the real profits unsatisfied. Besides, it may be short-term from the institutional imbalance to the condition of balance. It will be back to imbalance in the long run. Therefore, the policy objectives of the house property tax may not be exactly the same as the actual economic effects. The following is the analysis of the possible economic effects of policy objectives based on house property taxes.

House Property Tax Can Effectively Squeeze the Real Estate Market bubble. The most striking feature of the bubble economy is the severe deviation of price from the value of the goods, the supply and demand of commodities are seriously unbalanced, and the quantity supplied is much higher than the quantity demanded. In the long-term trend, with the development of urbanization, the demand of commercial housing will increase constantly. However, from the current stage, the supply of commercial housing is much larger than the actual demand of its residential attribute. A lot of money flow into the real estate market which makes commercial housing investment products to maintain and increase the value of assets. Through transferring from hand to hand frequently, it helps people make a profit by speculation. It leads to the high housing vacancy rate and forms the market bubble. So, the housing vacancy rate is the main characteristic of the real estate market bubble. Whether the house property tax can produce the economic effects of squeezing market bubble, the judgment standard is whether it can reduce the housing vacancy rate.

When the real estate speculators judge the value of housing investment, it is mainly based on the prospective price of the house and the cost of holding the house. As a kind of property tax, house property tax is a tax on house hold. It raises the holding cost of the building, and it also can reduce the speculators' expectations of the future price. As long as the tax rate of the house property tax reaches certain intensity, it will change the behavior of the speculators. For potential speculators, they will reassess the investment value of commercial housing, and be cautious to decide their own investment behavior, which will effectively suppress the growth of the market bubble. For those who have already owned several houses, they will have to consider selling or leasing their houses as soon as possible. Whether to sell or lease, and no matter how to deal with the real estate tax, the housing attribute will change from investment to residence.

Therefore, as long as the house property tax rate reaches a certain strength, it can reduce the housing vacancy rate, compress the economic effects of the real estate market bubble, and help the real estate market develop in a healthy and stable way.

House Property Tax Can Only Restrain the House Price in the Short Term. The house property tax can effectively squeeze the real estate market bubble, but it does not mean that house prices will fall sharply. In the short term, the house property tax can reduce the vacancy rate in commercial housing, increase the supply of commercial housing, restrain speculative demand and change the supply and demand elasticity of the commercial housing. It forms a policy shock to the commercial housing price. But in the long run, the house property tax has not changed the supply of land auction market and the demand rigidity of commodity transaction market. After the squeezed bubble has been digested by the market, the house property tax on the contrary will increased the proportion of government taxes and fees " $\mathrm{T}$ " in the constitution of the real estate price. After that, the housing price will rise back to the track.

The House Property Tax Can Only Have A Limited Fiscal Revenue Effect. Since the system of tax distribution has been implemented in our country, it resulted in the financial trouble of the local government because of the unreasonable distribution of authority and financial rights between the fiscal policy of central and local levels. It needs to expand fiscal revenue sources. Some scholars have analyzed the house property tax in some other countries and defined the top objective of our house property tax as local government revenue collection. (Huixia Fan, 2012)4. However, The reality of our country is different from those of other countries. The ownership of urban construction land in China is owned by the country, which provides the possibility for the local government to levy 
indirect taxes, such as the land leasing fee. The tax levied by the government from the real estate industry is mainly indirect taxes. If we keep using house property tax which is a kind of direct tax to replace it, then it will greatly increase the buyers' sense of "tax" and increase the cost of tax collection and administration. The direct policy objective of current real estate tax is to squeeze the market bubble. In the case of high housing price, for the residents who only have residential demand for housing, the government's rational choice is not to increase their tax bearing as much as possible.

Regardless of the pilots like Shanghai and Chongqing, or the prediction toward the probable full implementation of the house property tax rules, the house property tax will not tax on all housing owners. The number of houses and the areas owned by families with residential attribute are tax-free. In this case, the tax scope of house property tax is limited. As the property tax is implementing, the decline in the vacancy rate will further narrow the levy scope of the house property tax. As a result, it is unrealistic to expect the house property tax to bring substantial revenues for the local government.

The House Property Tax Can Play A Certain Effect on Income Distribution Adjustment. House property tax is a direct tax, which, in theory, is not easy to be transferred. But some scholars are skeptical. (like Yang Yan, 2017)5. His main basis is that the house property tax is not necessarily can cause the falling of house prices, so there will still be many people who can't afford to buy a house choose to rent, the rigid demand for the rental housing market still remains. When the vacancy rate is low and the rental market becomes smaller, the house property tax is easily passed on to low-income people who can't afford to buy. This plausible theoretical point only analyzes the changes in the supply side of the rental market and ignores changes in the demand side. Assume that the current housing sales and leasing market is balanced, after the implementation of house property tax policy, the most original vacant houses will flow to the housing sale market or leasing market. If it largely flows to the rental market, it will expand the rental housing supply, which goes against the transfer of house property tax. So the original vacant houses will be mostly flew to the sales market. That would reduce the price of the sales market, which meant that some renters would choose to buy a house rather than rent, and the leasing market would have less demand comparatively. Moreover, the demand elasticity of the leasing market is greater than the demand elasticity of the sales market. Because under the current household registration system in our country, renters, not like the buyers, can't get the household registration of the place where the house locates, which means they can't share the public goods such as education and health care equally. So, to sum up, the implementation of the property tax, whether in sales or leasing market, will ease the contradiction between housing supply and housing demand. The house property tax is not easy to transfer from a house owner to a renter. The house property tax can play a certain effect on income distribution adjustment.

\section{Policy Suggestions}

Fully Implement the House Property tax As Soon As Possible. Currently the real estate market bubble is serious in China. it is a serious threat to the real estate market and the stable operation of the whole national economic system. So it is urgent to suppress the real estate market bubble. Although the house property tax can't fundamentally change the short supply of the land and the demand rigidity of the commodity transaction market, it can effectively play an economic effect on squeezing the real estate market bubble and reduce the housing vacancy rate so that the housing attribute can return to residence. It can also control the risk of market bubble. Therefore, China should summarize the experience of Shanghai and Chongqing, fully implement the house property tax as soon as possible.

Set the Implementation Rules of House Property Tax Scientifically. In the case of the house property tax pilots in Shanghai and Chongqing, there is no expected economic effect. The reason is that the tax rate is too low and the tax targets are too few, and the taxation is not strong enough to affect speculators' behaviors and market expectations. Therefore, the full implementation rules of house property tax must be set scientifically. Such as raising tax rate, expanding the tax objectives, etc. In addition, the tax rate of house property can be excessive progressive tax rate in area and increase the income distribution and adjustment function of the house property tax. 
Plan the Purposes of House Property Tax Reasonably. Despite the local government lacks fiscal revenue sources, to solve the fundamental problem, the government must systematically reform the fiscal and taxation system, rather than pin their hope to increase tax bearing of the real estate industry. The real estate market should pay the tax on land sales, real estate development, real estate circulation and retention stage. The government's taxes is already a big part of the composition of high housing price. So the new house property tax must be applied to housing security. The pilot scheme of Shanghai and Chongqing, for example, is to use house property taxes for affordable housing and public housing, which should be fully promoted.

\section{References}

[1] Kanghua Zeng. Research on Contemporary Western Tax Theory and Tax Reform [M]. Beijing: China Tax Press, 2011.

[2] Shao'an Huang. Institutional Economics [M]. Beijing: Higher Education Press, 2008.

[3] Tianxiang Chen. Study on The Mode of Institutional Change in China [J]. Journal of Sun Yat-Sen University (social science edition), IssueNo.3, 2001.

[4] Cheng Gu. Home to House Property Tax: Theoretical Analysis and Policy Extension [J].Reform, Issue No.8, 2005.

[5] Huilan He. Study on The Effects of House Property Tax on The Price of Commodity Housing [J].Economics and Management, Issue No.9, 2008.

[6] Mingxing Pan, Jieru Wang. Thinking of House Property Tax Reform under Property Tax Attribute[J].Fiscal Research, Issue No.8, 2011.

[7] Shangmo Xia. House Property Tax: Can you Adjust Income Distribution Inequality and Restrain House Price? [J]. The Tax Research, Issue No.4, 2011. 